\title{
Formal Instruction in Second Language Teaching
}

\author{
Qian LI \\ Guangdong University of Foreign Studies, China
}

Received: 24 September 2019; Revised: 28 October 2019; Accepted: 7 November 2019; Published: 26 November 2019 Abstract: In second language acquisition, the role of form has been a controversial topic for half decade. Among a variety of language teaching approaches, the two extreme options--traditional grammar-translation approach and communicative language teaching approach-treat language forms in different ways. The disadvantages of those approaches are analyzed. An alternative approach, Focus on form (FonF) was proposed in an attempt to capture the strengths of the meaning-focus communicative approach while dealing with its limitations. The present paper analyzed the features of FonF and its application in different stages of task-based language teaching with the aim to further enhance the teaching efficiency in second language classrooms.

Keywords: The role ofform, Formal instruction, Second language teaching

\section{Introduction}

In language teaching and second language acquisition (SLA) theory, the role of language form and the issue of formal instruction are at the heart of debate and has been subject to controversy and discussion among researchers for at least 50 years (Ellis, 2001). There are two extreme options in language teaching concerning the role of form: traditional grammar-based instruction and meaning-focused communicative language teaching. In the former, the second language is broken down into discrete items which are taught separately and step by step with the assumption that acquisition is a process of gradual accumulation of parts until the whole structure of language has been built up (Wilkins, 1976). The role of learners is to synthesize these parts into a whole unit and then use it in communication. This is what Wilkins (1976) termed as synthetic approach. The general principle for the traditional grammar-based instruction is that grammar is the foundation upon which language learning should be based (Hinkel \& Fotos, 2002).

However, research on both SLA and psycholinguistics shows that second language acquisition is not a process of accumulating entities (Long, 1991; VanPatten, 1994). Language learning rarely happens with bits of language being learnt separately in an additive fashion. In addition, teachers cannot predict and determine what students are going to learn at any given stage (Willis, 1996). Traditional grammar-based instruction ignored the language learning developmental processes through which L2 learners normally pass, and the fact that progress is not necessarily unidirectional (Ellis 2008). Furthermore, as for the authenticity of the input, Widdowson (1989) states that as fabricated by teachers, the classroom interactions and the practiced language forms will not necessarily transfer to actual language use in real-life situations. As a result, traditional grammar teaching has failed to prepare learners for spontaneous, contextualized language use.

\section{Formal Instruction in Communicative Language Teaching}

Recognizing that treating the language purely as an object of study cannot develop the expected level of interlanguage proficiency, some researchers attempted to abandon grammar-based instruction in favor of more communicative-oriented language teaching which focused on language use (Nassaji \& Fotos, 2004). They argued that formal language lessons would develop only declarative knowledge of grammar structure, not the procedural ability to use forms correctly, and that there was no interface between these two types of knowledge since they existed as different systems in the brain (see review in Dekeyser, 2001). As such, they see formal instruction as unnecessary for interlanguage development.

Proponents of communicative teaching claim that people of all ages learn languages best by experiencing them as a medium of communication. The essence of communicative language teaching is the engagement of learners in communication to allow them to develop their communicative competence (Long \& Robinson, 
1998). Another tenet of communicative teaching is that exposing learners to large quantities of positive input that is comprehensible and meaningful is sufficient for language acquisition to occur. Grammar is acquired implicitly or incidentally (Krashen, 1985). This communicative language teaching approach underlies a variety of L2 classrooms, including those implementing Prabhu's procedural syllabus, Krashen's Natural approach, some content-based ELS instruction (e.g. immersion education), and task-based instruction.

However, research on the variations within communicative language teaching reveals at least the following problems (Long \& Robinson, 1998): first, learning an L2 through experiencing its use is possible, but it is inefficient. Learners who receive formal instruction of various kinds show higher levels of L2 proficiency than those only use the language (Norris \& Ortega, 2000). Secondly, due to the maturational constraints on language learning and the adoption of communicative strategies instead of taking risks for more advanced language in communication, adult learners may become fluent, but not nativelike speakers, despite plenty of learning opportunity. Even worse, a pure communicative language teaching may lead to fossilization of L2 acquisition (Schmidt, 1993; Skehan, 1998).

Thirdly, things are not clearly better among child learners. Here it is worth mentioning the immersion programs initiated in Canada. Immersion programs provides students with a rich source of comprehensible input in which the teaching of a second language is integrated with the teaching of content subjects. The goals of immersion education include both academic achievement in the content subjects, and a high level of proficiency in the second language (Swain \& Lapkin, 1995). However, even for the children who started the immersion education program in kindergarten, after many years of immersion, their productive skills remain far from nativelike, particularly with respect to grammatical competence (Swain \& Lapkin, 1995), although their comprehension abilities are indistinguishable from those of native speakers.

As such, the importance of attending to form becomes clear to both SLA researchers and teachers. Given that communicative language teaching by itself has been found to be inadequate (Ellis, 2002; Nassaji \& Fotos, 2004), pedagogical interventions need to be interwoven into primarily communicative activities so as to overcome the limitations of both traditional grammar instruction and communicative language teaching (Doughty \& Williams, 1998).

\section{Focus on Form: its Definition and Features}

In this context, researchers find it is necessary to look for an alternative approach, rather than to foster a single-sided teaching approach to promote both linguistic and communicative competence. Motivated pedagogically by the findings of immersion and naturalistic research mentioned above and theoretically by the notion of noticing and the Interaction Hypothesis (Long, 1983, 1996), focus on form (FonF) was proposed in an attempt to capture the strengths of the meaning-focus communicative approach while dealing with its limitations (Long \& Robinson, 1998). Since its conception, the idea of FonF has been widely advocated in the SLA literature. However, due to its popularity among researchers and teachers, there is considerable variation in how the term 'focus on form' is understood and used, and the construct has been interpreted and used differently by different researchers and teachers.

In his seminal work, Long (1991) initially introduced the notion of focus on form: 'focus on form...overtly draws students' attention to linguistic elements as they arise incidentally in lessons whose overriding focus is on meaning or communication' (Long, 1991, 45-46). Based on this theoretical notion, Long \& Robinson (1998) later raised a more pedagogically applicable definition of Focus on form as: 'focus on form consists of an occasional shift in attention to linguistic code features-by the teacher and/or one or more studentstriggered by perceived problems with comprehension or production' (Long \& Robinson, 1998, p23).

The idea of attention to form differs from explicit formal instruction. The definitions and the central features of FonF make FonF distinguishable from the notion of Focus on Forms (a term for traditional grammar teaching in Long, 1991) and Focus on Meaning (a term for meaning-focused communicative language teaching in Long 1991). Focus on Form entails a focus on formal elements of language with the prerequisite engagement in meaning, whereas Focus on FormS is limited to such an isolated language focus with no intention for effective communication, and Focus on Meaning excludes much effort concerning language elements (Doughty \& Williams, 1998, p. 4).

In Long's definition, FonF would be viewed as a responsive teaching intervention for online occasional attention shifts to problematic form in a communication setting. The problematic form occurs incidentally as a breakdown or error of some difficulty in either production or comprehension. From a pedagogical perspective, this means that teachers should wait for issues to emerge and respond to them as needed. 
Focus on Form has received sufficient attention in the L2 teaching field as well. Willis (1996) and Willis \& Willis (2007) propose a clear-cut distinction among focus on meaning, focus on language and focus on form. In their opinion, a focus on language is the option in which "learners pause in the course of a meaning-focused activity to think for themselves how best to express what they want to say, or a teacher takes part in the interaction and acts as a facilitator by rephrasing or clarifying learner language" (p.5). In contrast, a focus on form is an option in which one or more lexical or grammatical forms are isolated and specified for study, or in which the teacher comments on student language by drawing attention to problems. Similar to Long's definition, a focus on meaning is an option in which participants are concerned with communication (Willis \& Willis, 2007, p.5).

The varied interpretations and plethora of rather similar terms concerning Focus on Form have broadened our understanding of the notion of FonF (see review in Norris \& Ortega, 2000). As Doughty \& Williams (1998c) proposed, not limited to Long's implicit online FonF option, the pedagogical operation of FonF can be more flexible and diverse. It is reasonable to view FonF flexibly as a continuum from a most implicit, unobtrusive pole to an explicit obtrusive pole while meaning is always at the center of the activity and a problem trigger does exist. It is furthermore entirely possible to combine explicit and implicit FonF techniques, depending upon the particular acquisition circumstances (Doughty \& Williams, 1998c). There is growing evidence of the effectiveness of such a flexible curricular approach involving a variety of successful task-technique combinations (see review in Norris \& Ortega, 2000).

\section{Focus on Form in TBLT}

Unlike the extreme teaching approaches which stress either full formal instruction or pure communication within the L2, Focus on Form is an integration of both of these approaches. In other words, Focus on Form cannot exist in a vacuum, but should be embedded in a meaning-focused communicative setting. From a communicative perspective, the most effective way to assist language learning in the classroom is through communicative tasks (Nassaji, 2000). That is to say, tasks are an important component of communicative language teaching (CLT) (Ellis, 2003). Task-based language teaching, as a strong version of CLT, provides an optimal setting for the incorporation of focus on form (Long, 1991).

Based on the foregoing discussion of the defects of task-based instruction, Skehan (1996a) suggest that it may not be possible to rely on a task-based approach to automatically drive interlanguage forward...it is necessary, if task-based approaches to instruction are to be viable, to devise methods of focus on form without losing the values of tasks as realistic communicative motivators, and as opportunities to trigger acquisitional processes (Skehan, 1996a, p42).

This is a most important motivation for the incorporation of focus on form in task-based instruction. In recent decades, in task-based research and pedagogy, arguments have been made to interweave a concern for language form without compromising the communicative nature of the task (Bygate, Skehan \& Swain, 2001; Ellis, 2005; Fotos \& Nassaji, 2007; Norris \& Ortega, 2000; Skehan, 1996, 2003; Willis \& Willis, 2007). To add an option of FonF in task-based language teaching is appealing for the implementing of FonF in a communicative language teaching context (Skehan, 2007).

Researchers vary in their proposals for how this focus on form in task-based instruction can be best achieved. Within a task implementation framework, much of the task-based focus on form research falls into three categories: focus on form at pre-task, during task and post-task stages.

With regard to pre-task research, as Skehan (2007) pointed out, most task-based researchers, instead of investigating a wide range of pre-task activities (Willis, 1996), emphasize one influence only: pre-task planning (Mochizuki \& Ortega, 2008; Skehan \& Foster, 1997; Tavakoli \& Skehan, 2005; Yuan \& Ellis, 2003; Thai \& Boers, 2015). As far as the pre-task planning effect on language form (i.e. complexity and accuracy) is concerned, the research shows that pre-task planning has a stronger effect on fluency and complexity than on accuracy which means that during pre-task planning, learners give more attention to the content of the following performance rather than to the detailed linguistic forms used in the speech (Ellis, 2005).

With respect to focus on form at the during-task stage, researchers are mainly concerned with the effect of the interaction process, such as the efficacy of negotiation of meaning (Mackey, 1999; Van den Branden, 1997), and of corrective feedback, such as recasts, explicit corrective feedback etc (Ammar \& Spada, 2006; Doughty \& Varela, 1998; Lyster, 2004; Shintani, 2015; Van de Guchte et al, 2015; Nassaji, 2013). The research on negotiation of meaning shows that it is beneficial for learners' comprehension of input and then for their language development. In a recent meta-analysis on the effectiveness of corrective feedback(CF) in terms of grammar, Russell \& Spada (2006) find support for the effectiveness of corrective feedback for L2 grammar 
learning. Further, to some extent the benefits of $\mathrm{CF}$ are durable to the delayed post-tests. However, some researchers are doubtful about the effects of negotiation of meaning and recasts. They claim that it is likely that benefits of negotiation, whatever they might be, are not uniform (Pica, 2002). As such, it cannot be treated as a particularly dependable pedagogical technique. Pica (1997, 2002) and others (Foster, 1998; Williams, 1999) have claimed that negotiation in the classroom, either among learners or between learners and the teacher, is not as frequent as might be wished. Nor can transfer-of-information tasks guarantee that learners will negotiate (Foster, 1998). As for the effects of corrective feedback, Truscott $(1996,1999,2007)$ argues that the error correction in oral performance does not improve learners' ability in terms of grammar.

As compared to the numerous studies concerning focus on form at the pre-task or the within task stages, focus on form at the post-task stage has been surprisingly neglected by most task researchers to date (except Forster \& Skehan, 2013; Li, 2010; Lynch, 2001, 2007; Skehan \& Foster, 1997; Clennell, 1999; Mennim, 2003). Skehan \& Foster (1997) examined the effect of the foreknowledge of a certain post-task activity (to redo the task publicly) on three tasks (a personal, a narrative and a decision making task). They found that the clearest effect of a post task activity is on accuracy (an attractive index for the goal of focus on form). This supports the claim that a post task stage may be a desirable phase for promoting the effect of focus on form. Foster \& Skehan (2013) adopted another alternative post-task activity- "transcribing" to eliminate the disadvantageous influence of public performance. The results showed that (1) foreknowledge of transcribing as a post-task activity has a significant accuracy effect on task performance in both narrative and decision making tasks; (2) significantly greater complexity was found for the experimental group in the decision making task. (3) With regard to fluency, one of the measures, length of run, was significantly greater for the post-task condition in the decision making task. Li (2010) found that post-task transcription was effective in producing more accurate and complex language. In addition, pair-based transcribing was effective, although to a limited extent, for the improvement of syntactic complexity. The involvement of revision after transcribing brought about a positive effect on accuracy, but a negative effect on complexity.

From a teacher's perspective, Lynch (2001) investigated the variables of transcribing as a post-task activity in an L2 classroom setting. Lynch designed the activity to be conducted in pairs as collaborative transcribing. The analyses of the process and product of the cycles suggested that collaborative transcribing and revising can encourage learners to focus on form in their output in a relatively natural way. Furthermore, the teacher plays an important role in this post-task intervention, especially in the improvement of vocabulary. In a more recent study, Lynch (2007) compared the effects of two different transcribing groups-studentinitiated transcribing and teacher initiated transcribing. The analyses of the subsequent performance showed that both procedures are manageable under normal classroom conditions, and suggested that the studentinitiated transcribing was more effective in helping the learners to maintain higher accuracy in the highlighted forms which were revised by students themselves.

\section{Conclusion}

The issue of formal instruction in second language teaching has attracted the attention of teachers and researchers for at least half century. How to embed the formal instruction in the setting of communicative language teaching, e.g. task-based language teaching needs more concern from both language researchers and teachers so as to enhance the efficiency of language acquisition in second language classrooms.

\section{References}

Ammar, A., \& Spada, N. (2006). One size fits all: Recasts, prompts and L2 learning. Studies in Second Language Acquisition, 28, 543-574.

Bygate,M., Skehan, P., \& Swain, M. (Eds.). (2001). Researching pedagogic tasks: Second language learning, teaching and testing. Harlow: Longman.

Dekeyser, R. (2001). Automaticity and automatization. In P. Robinson, (Ed.) (pp.125-151). Cambridge: Cambridge University Press.

Doughty, C., \& Varela, E. (1998). Communicative focus on form. In C. Doughty \& J. J. Williams (Eds.) (pp.114-138). Cambridge: Cambridge University Press.

Doughty, C., \& Williams, J. (Eds.). (1998). Focus on form in classroom language acquisition. Cambridge: Cambridge University Press.

Ellis, R. (2001). Introduction: Investigating Form-Focused Instruction. Language Learning, 51, 1-46.

Ellis, R. (2003). Task-based language learning and teaching. Oxford: Oxford University Press.

Ellis, R. (2005). Planning and task performances in a second language. Amsterdam: John Benjamins.

Ellis, R. (2008). The study of second language acquisition (2nd edition). Oxford: Oxford University Press. 
Fotos, S., \& Nassaji, H. (Eds.). (2007). Form-focused instruction and teacher education: Studies in honor of Rod Ellis. Oxford University Press.

Hinkel, E., \& Fotos, S. (2002). New Perspectives on Grammar Teaching in Second Language Classrooms. Mahwah, NJ: Laurence Erlbaum Associates.

Krashen, S. (1985). The Input Hypothesis: Issues and implications. London: Longman.

Long, M. (1991). Focus on form: A design feature in language teaching methodology. In K.de Bot, R, Ginsberg, \& C. Kramsch (Eds.), Foreign language research in cross-cultural perspective (pp.39-52). Amsterdam: John Benjamins.

Long, M. (1996). The role of the linguistic environment in second acquisition. In W. Ritchie \& T. Bhatia (Eds.), Handbook of research on second language acquisition (pp.413-468). New York: Academic Press.

Long, M., \& Robinson, P. (1998). Focus on form: Theory, research and practice. In C. Doughty and J. Williams (Eds.) (pp.1541). Cambridge: Cambridge University Press.

Lyster, R. (2004). Differential effects of prompts and recasts in form-focused instruction. Studies in Second Language Acquisition, 26, 399-432.

Mackey, A. (1999). Input, interaction and second language development: An empirical study of question formation in ESL. Studies in Second Language Acquisition, 21, 557-587.

Mochizuki, N., \& Ortega, L. (2008). Balancing communication and grammar in beginning-level foreign language classrooms: A study of guided planning and relativization. Language Teaching Research, 12, 11-37.

Nassaji, H. (2000). Towards integrating form-focused instruction and communicative interaction in the second language classroom: Some pedagogical possibilities. The Modern Language Journal, 84, 241-250.

Nassaji, H. (2013). Participation Structure and Incidental Focus on Form in Adult ESL Classrooms. Language Learning, 63, 835-869.

Nassaji, H., \& Fotos, S. (2004). Current developments in the teaching of grammar. Annual Review of Applied Linguistics, 24, 126-145.

Norris, J., \& Ortega, L. (2000). Effectiveness of L2 instruction: A research synthesis and quantitative meta-analysis. Language Learning, 50, 417-528.

Schmidt, R. (1993). Awareness and second language acquisition. Annual Review of Applied Linguistics. 13, $206-226$.

Shintani, N. (2015). The Incidental Grammar Acquisition in Focus on Form and Focus on Forms Instruction for Young Beginner Learners. TESOL Quarterly, 49: 115-140.

Skehan, P. (1996). A framework for the implementation of task-based instruction. Applied Linguistics, 37, 38-62.

Skehan, P. (1998). A cognitive approach to language learning. Oxford: Oxford University Press.

Skehan, P. (2003). Task-based instruction. Language Teaching. 36, 1-14.

Skehan, P. (2007). Task research and language teaching: Reciprocal relationships. In Fotos, S., \& Nassaji, H (Eds.) (pp.55-69). Oxford University Press.

Skehan, P., \& Foster, P. (1997). The influence of planning and post-task activities on accuracy and complexity in task based learning. Language Teaching Research, 1, 185-211.

Swain, M., \& Lapkin, S. (1995). Problems in output and the cognitive processes they generate: A step towards second language learning. Applied Linguistics, 16, 371-391.

Tavakoli, P. \& Skehan, P. (2005). Planning, task structure, and performance testing. In R. Ellis (Ed) (pp.239-271). Amsterdam: John Benjamins

Thai, C., \& Boers, F. (2015). Repeating a monologue under increasing time pressure: Effects on fluency, accuracy and complexity. TESOL Quarterly,50, 369-393.

Van de Guchte, M., Braaksma, M., Rijlaarsdam, G, \& Bimmel, P. (2015). Learning new grammatical structures in taskbased language learning: The effects of recasts and prompts. The Modern Language Journal, 99, $246-262$.

Van den Branden, K. (2007). Second language education: Practice in perfect learning conditions? In R. Dekeyser (Ed.) (pp.161179). Cambridge: Cambridge University Press.

VanPatten, B. (1994). Evaluating the role of consciousness in SLA: terms, linguistic features, and research methodology. AILA Review, 11, 27-36.

Widdowson, H. (1989). Knowledge of language and ability for use. Applied Linguistics, 10, 128-137.

Wilkins, D. (1976). Notional syllabuses. Oxford: Oxford University Press.

Willis, D., \& Willis, J. (2007). Doing task-based teaching. Oxford: Oxford University Press.

Willis, J. (1996). A framework for task-based learning. Addison Wesley Longman Limited.

Yuan, F. \& Ellis, R. (2003). The effects of pre-task planning and on-line planning on fluency, complexity and accuracy in L2 oral performance. Applied Linguistics, 24, 1-27. 